\title{
China's Solar PV Manufacturing and Subsidies from the Perspective of State Capitalism
}

\author{
CHEN GANG
}

\begin{abstract}
This article examines how the Chinese government, at both central and local levels, has supported solar PV equipment manufacturing to increase its share in the global market, despite its innate disadvantages in this industry. Much of China's early expansion of manufacturing sectors can be attributed to its competitive advantages in cheap labour and good infrastructure, as well as the alleged undervaluation of the Chinese currency. However, China's formidable progress in the capital-intensive solar PV industries, where these advantages were no longer functioning effectively, has raised interesting questions about hidden stimulus factors like direct government subsidies, cheap land, technology support and easy credit provided by the government or other state sectors, like state-owned banks and research institutes. China's emergence as the world's largest manufacturer in these nascent industries has global economic repercussions. This research aims to explicate the Chinese business model from the perspective of state capitalism, a quasi-market system that has been integrated into the global economy, but which remains under the command of an authoritarian regime with a central planning mindset that makes innovative use of domestic leverages to subsidize strategic industries and achieve international competitiveness.
\end{abstract}

Keywords: China, Manufacture, Solar PV, State Capitalism, Subsidy

\section{Introduction}

With the new norm of carbon-constraints, in which emissions of greenhouse gases can no longer be assumed to be costless, solar photovoltaic (PV) electricity generation represents a promising renewable energy source. As a latecomer to PV production, China swiftly surpassed bellwethers like the United States and Japan by quadrupling its solar panel manufacture capacity between 2009 and 2011. By 2013, China accounted for 67 percent of the global module production, while the shares for Europe, Japan and the United States slid to 9 percent, 5 percent and 2.6 
percent, respectively (REN21 2014: 48). Massive investment and capacity built up in China led to serious oversupply in the international market and drove down module prices by more than 75 percent (REN21 2013: 47). As a result of China's fast-growing market share, both the EU and the United States launched anti-dumping and anti-subsidy investigations of the country's solar panel shipments, which became the biggest commercial disputes of their kind in history. ${ }^{1}$

The comparative advantages that China has accumulated during the short period in which it has been producing solar photovoltaic modules are outstanding, and defy standard explanations of China's manufacture competitiveness based on cheap labour, good infrastructure or the alleged undervaluation of the Chinese currency. In the nascent solar PV manufacture industry that has emerged amidst global concerns about climate change and energy security, labour formed just a tiny portion of manufacturing costs (Haley and Haley 2013: 1), while capital, technology, land, environmental regulation and scale of production are more crucial factors in determining competitiveness. China has been on the rise economically for more than three decades, successfully taking the position of the world's second largest economy and largest exporter. In the take-off stage of its economic miracle, much of China's competitiveness in manufacturing and exports was credited to abundant supply of cheap labour and land, which led to a high concentration of manufacturing sectors that produced low-value-added commodities, such as apparel, shoes, toys and kitchenware, for the global market.

However, since acceding to the World Trade Organization (WTO) in December 2001, China, a late-comer to modernization, propelled many of its industries upward along the global value chain and successfully captured the high ground in clusters of capital-intensive or tech-intensive manufacturing industries, among which steel, glass, paper, auto-parts and telecommunication products (smart-phones, tablets, etc.) were some of the best-known. Labour costs usually account for less than 10 percent of the total costs associated with these production activities and, more importantly, wages in the Chinese manufacturing sector experienced a 71 percent hike between 2008 and 2012, ${ }^{2}$ making China a much more expensive place for hiring workers compared to neighbouring countries, such as Vietnam and Cambodia. Thus China's traditional advantage of low cost labour could not fully explain its swift success in these industrial sectors.

As China's economic growth transcended its historical reliance upon labour-intensive industries to move towards capital-intensive industries, 
the country's exports have become markedly more sophisticated and contain more high-tech and machinery goods than pure comparativeadvantage theories had forecast. The exacerbated trade imbalance in China's favour has forced Western countries to pin their hopes of regaining industrial competitiveness on the development of newly-emerging manufacture sectors like the production of wind turbines and solar panels. However, even for such unploughed fields, in which China had no comparative advantage a decade ago, it has managed to snatch the high ground from the control of its formidable peers in the United States, Japan and Europe in a short period. Other major emerging economies like India or Brazil have failed to take such strides in this industry. In India, for example, most manufacturing capacity was idle or operating at low utilization rates, primarily because it was uncompetitive due to lack of scale, insufficient financing and under-developed supply chains (REN21 2014: 48).

China's explosive development in the new field of solar PV manufacturing, which could not be explained from the conventional perspective of comparative advantages, should instead be scrutinized through the theoretical lens of state capitalism, a common East Asian developmental model in which states play a significant and sometimes decisive role in industrialization and markets (Johnson 1995; Hobson 1997; Weiss 1998; Wong 2004; Fligstein and Zhang 2011). The Chinese model of state capitalism has been prominently discussed in the study of the country's meteoric economic growth in the past two decades (McGregor 2012; Lin and Jiang 2011; Fligstein and Zhang 2011; Nolan 2007). One of the fascinating aspects of this growth is the enormous subsidies provided in multi-layered, covert forms by the government. This study, using empirical evidence, aims to show that the Chinese government has substantially subsidized the strategically important solar PV manufacturing sector with producer subsidies, research grants, tax rebates, low-interest loans and cheap land. It argues that China would not have had such a competitive advantage if it had not been for such governmental intervention. Having sought to replicate aspects of the 'developmental state' model pioneered by Japan (Terry 2002), China's interventionist state approach in fact represents complex dialectical processes that have been shaped by and have responded to a complex array of contingent economic and political forces. Compared with the Japanese developmental pattern, in which central government agencies simply planned the development process and calibrated industrial policies (Beeson 2009: 9), China's state capitalism encourages both central 
and local governments to play a straightforward role in supporting local industries with various forms of financial aid and services. China's developmental miracle owes much to the socialist heritage of the Maoist era, which instituted a strong Leninist party-state and a concentration of power in the Communist Party of China (Walder 1994: 297-323). This model tends to promote state-owned enterprises (SOEs) at the expense of private actors in pillar industries (zhizhu chanye), but for emerging industries (xinxing chanye) where no national champions can be identified, the local authorities are often ready to offer generous help for these indigenous firms, regardless of their ownership structures.

Porter's national competitiveness theory argued that governments, by reshaping factor conditions, demand conditions, related industries and firm strategy, ${ }^{3}$ can play an indirect role in helping industries gain competitive advantages (Porter 1998: 72-127). Using the case study of China's solar subsidies, this article aims to reveal through what means government agencies, under the Chinese pattern of state capitalism, are helping indigenous industries to be competitive internationally. The study focuses on the real impact of government subsidies and other forms of support on factor and demand conditions, supporting industries and firm strategy.

\section{China Lacks Innate Competitiveness in Solar PV Manufacturing}

The exploration of solar energy to date is divided into two main categories: solar thermal for the use of solar heat and solar PV for electricity power generation. China, as the largest market for solar thermal applications, has a long history of utilizing solar thermal technologies, but it is a late-comer for solar PV manufacture and application compared to industrial pioneers like Germany, Italy and the United States. In its infant stage of solar PV manufacture, China was weak in terms of technologies for producing the raw material for solar PV, polycrystalline silicon. Despite the establishment of a number of research institutes and universities dedicated to research and development (R\&D) for solar PV between 1986 and 2005, advancement of PV technologies was slow in China (Yang and Pan 2010: 14). In the early days, China did not have competitive PV-related knowledge resources that resided in universities, government research institutes, private research facilities, business and scientific literature and market research databases (Chen 2015: 101). China had to import 95 percent of its PV raw materials due to a lack 
of advanced technologies for producing polycrystalline silicon, and it exported 95 percent of its finished products due to an underdeveloped domestic market (Li 2010: 38; Chen 2015: 98). In the solar PV industrial chain that includes production of crystalline silicon, silicon ingot and wafer, solar cells, modules and arrays, China was only able to manufacture a small proportion of global silicon material in the upstream while it accounted for about half of global production capacity for cells and modules in the downstream. In the nascent stage, China was weak in the upstream of the PV industrial chain, namely silicon production, while it was strong in the labour-intensive downstream, including cell production and PV module encapsulation (see Table 1).

TABLE 1: China's Manufacturing Capability in the Solar PV Industrial Chain (2008-2009)(Yang and Pan 2010:25)

\begin{tabular}{|l|l|l|l|l|l|}
\hline $\begin{array}{l}\text { Industrial } \\
\text { Chain }\end{array}$ & Silicon & Ingot/Wafer & Cells & Modules & PV Arrays \\
\hline Features & $\begin{array}{l}\text { Capital-in- } \\
\text { tensive; high } \\
\text { technical } \\
\text { threshold; } \\
\text { long } \\
\text { payback } \\
\text { period; } \\
\text { high energy } \\
\text { consumption; } \\
\text { and poison- } \\
\text { ous emis- } \\
\text { sions. }\end{array}$ & $\begin{array}{l}\text { High techni- } \\
\text { cal barrier; } \\
\text { decrease in } \\
\text { the thick- } \\
\text { ness of sili- } \\
\text { con wafers } \\
\text { is an effec- } \\
\text { tive way to } \\
\text { reducing the } \\
\text { cost of PV } \\
\text { cells. }\end{array}$ & $\begin{array}{l}\text { Large-scale } \\
\text { is cruction } \\
\text { medium- } \\
\text { level capital } \\
\text { and techni- } \\
\text { cal thresh- } \\
\text { old. }\end{array}$ & $\begin{array}{l}\text { Low capital } \\
\text { and technical } \\
\text { threshold; } \\
\text { labour-inten- } \\
\text { sive; short } \\
\text { payback } \\
\text { period; and } \\
\text { fierce compe- } \\
\text { tition. }\end{array}$ & $\begin{array}{l}\text { Low } \\
\text { technical } \\
\text { threshold } \\
\text { but com- } \\
\text { prehensive } \\
\text { use of com- } \\
\text { bined tech- } \\
\text { nologies is } \\
\text { required. }\end{array}$ \\
\hline $\begin{array}{l}\text { Manu- } \\
\text { facturing } \\
\text { Competi- } \\
\text { tiveness in } \\
\text { China }\end{array}$ & Weak & Medium & Strong & Strong & Strong \\
\hline
\end{tabular}

Production of high purity polycrystalline silicon, the basic feedstock of solar cells, has always been the cause of China's bottleneck situation in the industrial chain ( $\mathrm{Li}$ and Ma 2009). Despite its rich silicon reserves, China was lagging behind in the processing of silicon purification at the international level in the mid-2000s; much of its high energy consumption and emission of poisonous waste was owing to backward technologies and lack of strict regulation. Although challenges such as low efficiency and pollution also existed in other countries, China's situation was more extreme. As for the ingot and wafer production, the second stage of the industrial chain, China's silicon ingot slicing indus- 
try was relatively mature at the international level, with thinner wafers developed and thus less silicon feedstock needed. However, since the status of silicon ingot and wafer production is still largely dependent on the silicon feedstock, there was still a significant gap between China and some industrialized countries in terms of wafer production skills. In contrast to its weak competitiveness in the upstream, China was strong in the downstream solar cell manufacturing and module encapsulation in which the advantage of low labour costs is particularly important.

The high energy consumption and emission of poisonous waste in the production of high purity polycrystalline silicon have added both economic and ecological costs to China's PV manufacturing efforts. China's early solar production was beset by problems similar to those that India's PV production is now facing: high levels of pollution and high energy costs, fragmented manufacturing capacity, lack of scale, an underdeveloped local capital market and lagged research and development.

The explanation for China's later triumph and India's stagnation in PV production can be found through the study of factor distortion under the framework of state capitalism. Historically, India has had more of a free-market orientation than China, ${ }^{4}$ and its state sector is more fragmented, decentralized and less interventionist when compared to China's government apparatus. Sharing a similarly humble industrial basis, China's PV manufacturing has outrun India's, largely due to the interventionist role played by a strong Chinese government.

\section{Subsidies under State Capitalism}

China is a game-changer in global solar PV manufacturing, as its revenue share in the world market surged from an insignificant portion before 2005 to more than 50 percent in 2011 and 2012. Since the production of solar cells and modules is a capital- and tech-intensive industry in which China had no comparative advantage a decade ago, its swift success in snatching up the high ground from the control of formidable peers in the United States and Europe has shocked many industrial observers, particularly those with the expectation that the Western world should alleviate the trade imbalance through the development this high-tech sector. China's existing production capacity for solar panels was about 150 percent of global real demand in 2012, and in just four years between 2009 and 2012, the international price of solar panels had been cut by more than 75 percent, largely due to an aggressive capacity build-up 
in China (REN21 2013: 47). Both the EU and the US authorities have accused China of illegal state subsidies and widespread dumping in the drive for industrial competitiveness, though this doesn't take into account the reality that EU and US production costs were actually lower China's. As noted, compared with other industrialized nations, China is well-known for its advantages in the supply of cheap labour; but in solar PV manufacturing, labour accounts for a small part, less than 10 percent of total cost (Chen 2015: 101). Both the EU and US authorities found that the Chinese government's generous subsidies had helped its PV producers to gain comparative advantages by reshaping the country's factor conditions, which included human resource input, infrastructure, knowledge resources and the capital market.

Porter's theory links government industrial policies to the economic successes of some East Asian countries, whose comparative advantages benefit indirectly from these policies that reshape the circumstances of the four determinants in a positive way (Porter 1998: 126). In these developmental states, factor conditions like labour, land, raw materials, capital, and infrastructure are often remoulded by the government through subsidies and supportive policies, while indigenous demand can also be reframed by local product standards, government procurement and consumption subsidies. Under the Chinese model of state capitalism in which many manufacturing industries are backed by proactive government policies, China's solar panel production has long featured the highest localization rates for its equipment, the lowest technological threshold, the largest number of small- and medium-sized businesses, and the greatest expansion in the global PV manufacturing industry.

China's 11th Five-Year Plan (2006-2010), the Renewable Energy Law (2005) and its amendment (2009), as well as the Medium- and LongTerm Development Plan for Renewable Energy (2007) have provided programmatic guidance systems for the government support of domestic solar manufacture. Since 2008, when China's exports were hit hard by the global financial crisis, the central government has asked local governments to support renewable energy industries as emerging industries of strategic importance (zhanlue xinxing chanye), which could serve as a new engine for strong economic growth. Following what had been done in supporting heavy and chemical industries in the 2000s, the multi-layer government apparatus subsidized domestic solar panel production in a similar way, providing cheap land-use rights, cheap credit, tax rebates, research funds, and sometimes even straight-up cash. 


\section{Major Forms of Chinese Subsidies}

As with other manufacturing sectors, the Chinese government, at both central and local levels, provides factories along the industrial chain of PV manufacturing with various forms of subsidies, which include free or low-cost loans, tax rebates, research grants, cheap land, energy subsidies and technological, infrastructure and personnel support. One of the easy ways for local governments to support indigenous PV producers is to instruct local commercial banks to offer bountiful loans at low interest. By lowering the costs of capital, subsidized credit supports PV manufacturers regardless of their productivity levels, even if some of these loans may face high risk of default. In many cases, local officials encouraged entrepreneurs to take more loans from local banks for capacity expansion, regardless of oversupply and competitiveness problems. It was reported that in 2005, after a mere half-an-hour conversation with Peng Xiaofeng, CEO of LDK Solar (which later became the world's secondlargest maker of solar wafers), Mayor Wang Dehe of Xinyu City, Jiangxi Province, immediately asked local banks to provide loans worth of 200 million yuan (US\$ 26 million) for the start-up. ${ }^{5}$ Between 2005 and 2012, the local bank loans accredited to Wuxi Suntech Power Co. Ltd, once China's largest PV manufacturer, jumped from US\$ 56 million to US\$ 3.7 billion, largely due to a municipal government mandate on local state-owned banks for providing low-interest loans to Suntech. ${ }^{6}$ From 2006 to 2011, Wuxi Suntech also received tax rebates and other forms of refund amounting to 8.65 billion yuan (about US\$ 1.42 billion) from the government with the aim of promoting exports. ${ }^{7}$

This huge credit influx into domestic PV manufacturing exacerbated the existing overcapacity and debt issues. By August 2012, China's top ten PV makers had already accumulated a combined debt of US\$17.5 billion, leading the whole industry to the brink of bankruptcy. ${ }^{8}$ Despite this worsening debt, local governments, to protect local GDP growth and employment, continued to grant financial aid in all forms to save plants from being closed down. Under the framework of state capitalism, staterun banks offer interest subsidies to loans for PV manufacturing and related technology $R \& D$, a key sector that China wanted to support as a new growth point in the aftermath of the global financial crisis. Rocketing bank loans as a result of government connivance exacerbated the overcapacity and debt problems of Wuxi Suntech, which was experiencing weak sales and on the brink of bankruptcy in 2012. Ignoring the principle of prudence, the Wuxi municipal government still gave directives to the 
local subsidiary of Bank of China, asking it to disregard the risk of default and grant emergency loans of 200 million yuan to the company. ${ }^{9}$

Besides direct fund injection, provision of cheap land is another approach often used by local governments to promote local PV production and investment. Most PV producers need sizable industrial land for assembling production lines, $\mathrm{R} \& \mathrm{D}$, logistical purposes, and waste and pollution treatment, but in the start-up phase, they usually lack sufficient funds or collateral to acquire this. Local governments, through confiscating land from villagers, urban residents or other factories at very low prices, often have abundant landbanks to support all kinds of industrial enterprises. In the start-up stage in 2005, the Jiangxi-based LDK Solar asked for land of 7,012 $\mathrm{mu}$ (467 hectares) from the Jiangxi provincial government, which at that time had no extra land-use quota for large manufacturers. Jiangxi nonetheless granted land of 15,000 mu to LDK Solar, most of which was newly confiscated farmland leased to LDK at very low prices. ${ }^{10}$ To attract prominent domestic PV manufacturers to build their production lines in Heyuan City, Guangdong Province, the Guangdong provincial government not only shortened the approval process for any new PV manufacturing projects to only five working days, but also persuaded other enterprises in the same industrial park to accept land reallocation without compensation. One factory which had to concede part of its land right to incoming PV manufacturers had asked for economic compensation amounting to 40 million yuan, but following interference from the local government it eventually withdrew its claim. ${ }^{11}$

As with many industrial sectors in China, energy consumption is also subsidized extensively to lower costs and thus promote the competitiveness of local PV producers. As most solar PV manufacturers are electricity guzzlers, such energy subsidies in the forms of preferential electricity prices and power infrastructure support are vital for the survival of these producers in fierce competition with their domestic and international peers. Electricity prices have been tightly controlled by the Price Bureau of the National Development and Reform Commission (NDRC), the powerful department in charge of economic plans inside the State Council, China's cabinet. When setting power prices, the NDRC usually accommodates provincial stakeholders' interests and, in most cases, provincial officials lobby for end-users to price low enough to keep their ind ustries viable and competitive. China has set electricity tariffs lower than supply costs and lower than the tariffs in developed countries, and although electricity prices for Chinese industry appear 
higher than those for residential use, in practice many companies do not bear the full costs indicated by the official average figures, with subsides or 'price adjustments' permeating the system (Haley and Haley 2013: 38-39). Industrial sectors consume about three quarters of the total electricity generated in China, with local economic and social concerns often propelling local governments to grant power price concessions to high-energy-consuming industries. China's State Electricity Regulatory Commission once openly criticized the Sichuan and Heilongjiang provincial governments in its annual report for subsidizing local highenergy-consuming enterprises like solar PV manufacturers and chemical factories by arbitrarily lowering the on-grid electricity prices sold to them. According to the report, between January and May 2010, the Heilongiiang provincial government lowered the selling price of energy for PV producers and other energy guzzlers from 533 yuan per thousand kwh to 480 yuan per thousand kwh, which helped these companies collectively save 100 million yuan after they had bought electricity of 753 million kwh at this preferential price during that period (China's State Electricity Regulatory Commission 2011: 13-14). Provincial governments sometimes broker special deals for large PV producers that have a significant impact on the local economy, or they build extra power facilities to ensure a direct electricity supply. In response to the enormous energy appetite of LDK Solar, the state-owned power company in Xinyu City also built six transformer substations with a total capacity of $1,520,000$ KVA (1,000 volt-amperes), equal to the capacity of the power grid in western Jiangxi Province, for the sole use of LDK Solar. ${ }^{12}$

The government, at multiple levels, also gave technological, infrastructure and personnel support to local solar panel producers to enhance their competitiveness in this tech- and capital-intensive industry. Yingli Solar, the world's biggest manufacturer of solar PV, is based in northern China's Hebei Province. It has succeeded in setting up two laboratories for photovoltaic technology, with substantial tech, financial and personnel support from the Chinese Ministry of Science and Technology and the National Energy Commission under China's National Development and Reform Commission (NDRC), respectively. The government provided these renewable energy labs with generous hardware (facilities, infrastructure and funding) and software (policy, research staff) support, which could help local enterprises to cut the costs of R\&D. ${ }^{13}$ ( Yingli Solar set up its own PV laboratory in January 2010, but a large part of its initial investment of 540 million yuan actually came from the government instead of Yingli. ${ }^{14}$ 
While contributing the largest portion to global PV production, China accounted for a disproportionately low share of worldwide accumulative PV power generation capacity. Taking advantage of the global trend focusing on fossil fuel replacement amidst growing public awareness of climate change, China's early support for the PV industry focused on reshaping factors of production rather than home demand conditions. Dominated by concerns that the exorbitant cost of installing and operating PV facilities could be a heavy financial burden on the government, the state apparatus at both the central and local levels preferred to generously subsidize PV production aimed at the overseas market rather than endorsing nationwide feed-in tariffs that supported domestic PV consumption up until 2011. This strategy under the Chinese model of state capitalism helped the country to net bountiful trade surplus while its solar panel exports enjoyed twofold benefits from domestic production subsidies and overseas consumption-end subsidies in the name of $\mathrm{CO} 2$ mitigation. Ironically, the stimulation of PV production in the name of green development and sustainable growth did not contribute much to the improvement of China's own air quality and mitigation causes; on the contrary, China has ended up with serious pollution, high energy consumption and extensive debt problems associated with domestic overcapacity. Only under such circumstances did the Chinese government shift its state strategy from subsidizing PV producers to subsidizing demand-end power generation, extending an above-market-price feed-in tariff across the entire country for the first time in 2011. Nevertheless, the various state subsidies offered to domestic PV producers have not ceased under the mercantile model of state capitalism, which still values the expansion of trade surplus and accumulation of foreign reserves as its persistent national goals. The government has bailed out major solar panel makers like Wuxi Suntech and Shanghai Chaori from time to time. Shanghai Chaori, which defaulted in the country's onshore bond market, got a guarantee of as much as 788 million yuan (US\$128.4 million) from China Great Wall Asset Management Corporation on the solar-panel maker's 1 billion yuan of defaulted notes. ${ }^{15}$

\section{Domestic and International Implications}

The continuous overexpansion of solar PV manufacture, fuelled by state subsidies, cheap land and credit, as well as tax rebates, has profound domestic and international implications, forcing some domestic manufacturers into bankruptcy on the one hand, and triggering international 
trade disputes with the EU and US on the other. Although the overcapacity of solar PV production is global, with prices of solar panels having plunged in the past few years, this issue has been extremely serious in China, where PV manufacturing has been supported as a strategically important emerging industrial sector that has the potential to bring profitability and employment to the country. In the solar PV sector, thanks to an aggressive capacity build-up in China and elsewhere, the average price of crystalline silicon solar modules fell by 30 per cent or more in 2012, while thin film prices dropped about 20 percent. China's module production capacity alone exceeded the global market demand.

The overexpansion of China's solar PV sector has not only led to the price slump on the international markets and squeezed out foreign producers, it has also wiped out indigenous manufacturers and caused domestic debt and unemployment problems. In October 2012, the US Department of Commerce set anti-dumping duties ranging from 18.32 percent to 249.96 percent on Chinese silicon photovoltaic imports and, in May 2013, the European Commission decided to levy preliminary duties of around 47 percent on Chinese solar panel imports. In 2012, the US Department of Commerce also imposed anti-dumping duties of 47.59 percent on wind-turbine towers from Chengxi Shipyard and 44.99 percent for Titan Wind Energy Suzhou Co., both based in China.

Growing trade disputes and price slumps have put some major manufacturers in China under threat. Suntech Power Holdings of Wuxi, China's Jiangsu Province, one of the world's biggest solar panel manufacturers, was forced into bankruptcy court in March 2013, after running short on cash. It was only one of the emblematic solar panel makers to have suffered huge losses and laid off workers, after overestimating demand for their products and encountering plunging prices. Facing insufficient cash flow, weak sales, and sliding gross profit, Sinovel Wind Group, a major Chinese wind turbine maker, laid off 350 new graduates in May 2012 and put another 350 workers, 12 percent of its total number of employees, on leave in November 2012. Since an economic slowdown in China is exacerbating the issue of excess capacity, more domestic suppliers in the solar and wind sectors are expected to be pushed to the edge of collapse, with massive debt and weakening demand threatening their survival. 


\section{Conclusion}

The Chinese model of state capitalism, often discussed in the understanding of the country's meteoric economic growth over the past two decades, has played a crucial role in reshaping the domestic industrial and market circumstances that help domestic PV producers to gain comparative advantages over their international peers. This study has indicated that massive government subsidies profoundly reshaped factor conditions (capital, land, human resources) and supporting industries (power supply, infrastructure, etc.) to help indigenous solar PV firms gain competitive advantages over their foreign rivals. Nonetheless, even in the model of state capitalism, Porter's proposition still stands, as governmental interventions, regardless of their forms, can only exert indirect influences upon industrial competitiveness and are not direct determinants of national advantages.

Since an economic slowdown in China has been exacerbating the issue of excess industrial capacity, more domestic suppliers in the solar sectors are expected to be pushed to the brink of collapse without robust governmental subsidization of domestic solar PV power generation. Porter's theory suggests that if the Chinese government succeeds in reshaping the domestic demand conditions it once ignored through vigorously subsidizing PV power generation, China's competitiveness in PV manufacturing should be further uplifted. As an example exemplifying the affinity between the country's many successful manufacturing industries and corresponding huge-sized domestic markets that nurture them, the development, generation and consumption of solar power are conducive to enhancing the competitiveness of solar panel manufacturing, by providing a sustainable and stable domestic market demand (Zhang et al. 2013).

The declining cost of solar electricity and the need to control CO2 emissions have pushed the government to nurture the domestic market more actively. Research has shown that in 2020, PV power generation in China could save 17.4 Mtce fossil energy and 46.5 Tg CO2 compared with 600 MWe coal-fired supercritical units (Wang et al. 2014: 370). Also projected for 2020, the costs of solar electricity could be reduced by approximately 60 percent as compared to 2010, and in economically developed provinces, the PV electricity is $0.67-0.86 \mathrm{RMB} / \mathrm{kWh}$, which is close to grid parity owing to high grid prices (Ibid.).

Among China's four major sources of low-carbon power generation (hydro, nuclear, wind and solar), solar PV power generation has been 
the least developed, with on-grid solar accounting for less than 0.1 percent in the country's energy mix in 2012 (China Electricity Council 2013). China's solar power generation, decoupled from the overheated domestic solar PV manufacturing, remains underdeveloped. In view of the extensive subsidies and other incentives to be offered by the government in the next few years for the deployment of large-scale solar PV projects across the country, China's PV installed capacity is destined to grow exponentially. Such a policy reorientation for the domestic market is sending signals to manufacturers that the government has the longterm planning horizon necessary to allow them to reasonably invest in R\&D and local manufacturing infrastructure (Lewis and Wiser 2007). According to Porter's model of national competitive advantage, the revitalization of the once-ignored domestic demand is expected to form a positive feedback effect upon China's PV manufacturing competitiveness that has been hit hard by trade disputes and overcapacity.

Chen Gang is Research Fellow at the East Asian Institute, National University of Singapore. He has published extensively on China's environmental and energy policies and is the author of China's Climate Policy (2012, London: Routledge) and Politics of China's Environmental Protection: Problems and Progress (2009, Singapore: World Scientific).Email: eaicg@nus.edu.sg

\section{NOTES}

1 Bloomberg Business, 3 December 2013, 'EU Nations Approve Pact With China on Solar-Panel Imports.' Available at http:/ / www.bloomberg.com/news/articles/201312-02/u-nations-approve-pact-with-china-on-solar-panel-trade. Accessed 5 April 2014.

2 The Wall Street Journal, 17 May 2013, 'Rising Wages Pose Dilemma for China.' Available at http:/ / online.wsj.com/news/articles/SB100014241278873247670045784882 33119290670. Accessed 26 February 2014.

3 He called these the 'four determinants of national competitive advantage'.

4 Shilling, A. Gary 2012. 'India's Accelerating Shift Toward Free Markets.' Bloomberg View. http:// www.bloombergview.com/articles/2012-12-17/india-s-acceleratingshift-toward-free-markets. Accessed 26 December 2014.

5 Meiri Jingii Xinwen 22 June 2012. 'Guangfu Yuejin Zhi Hangye Fansi: Difang Zhengfu de Chongdong Yu Niai' ('Reflection on PV expansion: impulse from local governments') at http:/ / finance.sina.com.cn/chanjing/cyxw/20120622/014712378110. shtml. Accessed 1 April 2014.

6 China Business Times, 28 March 2013. 'Shangde Jiaocha Weiyue Jingneiwai Zhaiquan Youbie' ('Different impact of Suntech's default in domestic and overseas bond market') at http://business.sohu.com/20130328/n370658622.shtml. Accessed 1 April 2014.

7 Ibid. 
8 Caijing, 8 August 2012. 'China's Photovoltaic Industry on Brink of Bankruptcy: Report' at http://english.caijing.com.cn/2012-08-08/111998243.html. Accessed 1 April 2014.

9 China Business News, 28 September 2012. 'Shangde Huo Wuxishi Zhengfu Zhichi' ('Suntech Got Support from Wuxi Government') at http://news.xinhuanet.com/ fortune/2012-09/28/c_123772652.htm. Accessed 2 April 2014.

10 Meiri Jingji Xinwen, 22 June 2012.

11 Ibid.

12 Meiri Jingji Xinwen, 22 June 2012.

13 Interview with NDRC policymakers, Beijing, 2 March 2012.

14 See Yingli Solar at http:// www.yinglisolar.com/en/. Accessed 10 July 2014.

15 China Great Wall Asset Management Corporation, established by the Chinese government in 1999, is a state-backed fund that helps large-sized companies, most of which are state-owned enterprises, to restructure their bad debts in the domestic market. See Bloomberg News, 8 October 2014, 'China's First Bond Defaulter Gets Guarantee From Bad Bank.' Available at http://www.bloomberg.com/news/articles/201410-07/ chaori-solar-restructuring-plan-seeks-haircuts-up-to-80-. Accessed 1 January 2015.

\section{REFERENCES}

Beeson, M. 2009. 'Developmental States in East Asia: A Comparison of the Japanese and Chinese Experiences.' Asian Perspective 33(2): 5-39.

Bremmer, I. 2010. The End of the Free Market: Who Wins the War Between States and Corporations? New York: Portfolio.

Buckeridge, D.L., R. Glazier, B. J. Harvey, M. Escobar, C. Amrhein and J. Fran 2002. 'Effect of motor vehicle emissions on respiratory health in an urban area.' Environmental Health Perspectives 110 (3): 293-300.

Chen, G. 2012. China's Climate Policy. London: Routledge.

Chen, G. 2015. 'From mercantile strategy to domestic demand stimulation: changes in China's solar PV subsidies.' Asia Pacific Business Review. 21 (1): 96-112.

China Electricity Council 2013. 'Statistical Brief on China's Electricity Industry in 2012' (zhongdianlian fabu 2012nian quanguo dianligongye yunxing jiankuang) http:/ / www.cec.org.cn/guihuayutongji/gongxufenxi/dianliyunxingjiankuang/2013-0118/96374.html. Accessed 30 January 2013.

China's State Electricity Regulatory Commission 2011. Power Industry Monitoring and Supervision Report 2010 (2010 niandu dianjia zhixing ji dianfei jiesuan qingkuang tongbao). Beijing: State Electricity Regulatory Commission.

Dulal, H. B., K.U. Shah, C. Sapkota, G. Uma and B. R. Kandel 2013. 'Renewable energy diffusion in Asia: Can it happen without government support?' Energy Policy. 59: 301-311.

Fligstein, N. and J. Zhang 2011. 'A new agenda for research on the trajectory of Chinese capitalism.' Management and Organization Review 7(1): 39-62.

Haley, U. C.V. and G. T. Haley 2013. Subsidies to Chinese Industry: State Capitalism, Business Strategy, and Trade Policy. New York: Oxford University Press.

Hobson, J. M. 1997. The Wealth of States. Cambridge: Cambridge University Press.

Fligstein, N. and J. Zhang 2011. 'A New Agenda for Research on the Trajectory of Chinese Capitalism.' Management and Organization Review 7 (1): 39-62.

Huang, Y. and B. Wang 2010. 'Cost distortions and structural imbalances in China'. China and World Economy 18 (4): 1-17. 
Johnson, C. 1995. Japan: Who Governs? The Rise of the Development State. New York: Norton.

Lewis, J.I. and R.H. Wiser 2007. 'Fostering a Renewable Energy Technology Industry: An International Comparison of Wind Industry Policy Support Mechanisms.' Energy Policy 35: 1844-1857.

Li, Junfeng and Ma, Lingjuan 2009. 'Background Paper: Chinese Renewables Status Report.' http://ren21.net/Portals/0/documents/Resources/Background_Paper_ Chinese_Renewables_Status_Report_2009.pdf. Accessed 20 December 2013.

Li, Lei 2010. 'Brief analysis of current China's PV industry: Part II' (woguo guangfuchanye fazhanxianzhuang jianxi zhier). in Solar \& Renewable Energy Sources (yangguang nengyuan). 2: 36-39.

Li, Ling 2007. 'China Urges Electricity Suppliers to Buy 'Green' Power.' http:/ / www. renewableenergyworld.com/rea/news/article/2007/09/china-urges-

electricity-suppliers-to-buy-green-power-49879. Accessed January 2012.

Lin, B. and Z. Jiang 2011. 'Estimates of energy subsidies in China and impact of energy subsidy reform.' Energy Economics 33: 273-283.

McGregor, J. 2012. No Ancient Wisdom, No Followers: The Challenges of Chinese Authoritarian Capitalism. Westport: Prospecta Press.

McGregor, R. 2010. The Party: The Secret World of China's Communist Rulers. New York: HarperCollins.

National Development and Reform Commission 2013. 'Guojia Fazhan Gaigewei Guanyu Fahui Jiage Ganggan Zuoyong Cujin Guangfu Chanye Jiankang Fazhande Tongzhi' ('NDRC's Circular on the Promotion of Solar PV Sector through Price Leverage') at http://www.sdpc.gov.cn/zfdj/jggg/dian/t20130830_556127.htm. Accessed 26 August 2014.

Nolan, P. 2007. Capitalism and Freedom: The Contradictory Character of Capitalist Globalization. London: Anthem Press.

Porter, M.E. 1998. The Comparative Advantage of Nations: With a New Introduction. New York: The Free Press.

PRC 'Zhonghuarenmingongheguo Kezaisheng Nengyuanfa Xiuzhengan' ('Amended Law on Renewable Energy') 2009. www.npc.gov.cn/npc/xinwen/2009-12/26/content_1538199.htm. Accessed 3 January 2014.

PRC Renewable Energy Law. 2005. www.renewableenergyworld.com/assets/download/China_RE_Law_05.doc. Accessed 8 January 2014.

REN21 (Renewable Energy Policy Network for the 21st Century) 2009. Recommendations for Improving the Effectiveness of Renewable Energy Policies in China www.ren21.net/ pdf/Recommendations_for_RE_Policies_in_China.pdf. Accessed 30 January 2012.

REN21 (Renewable Energy Policy Network for the 21st Century) 2013. Renewables 2013 - Global Status Report. http://www.ren21.net/Portals/0/documents/Resources/GSR/2013/GSR2013_lowres.pdf. Accessed 29 July 2013.

REN21 (Renewable Energy Policy Network for the 21st Century) 2014. Renewables 2014 - Global Status Report. http://www.ren21.net/REN21Activities/GlobalStatusReport.aspx. Accessed 28 November 2014.

Salim, R.A. \& S. Rafiq 2012. 'Why do some emerging economies proactively accelerate the adoption of renewable energy?' Energy Economics 34 (4): 1051-1057.

So, Alvin Y. 2002. 'Guest Editor's Introduction.' Chinese Economy 35(3): 6.

Terry, E. 2002. How Asia Got Rich: Japan, China, and the Asian Miracle, Armonk, N.Y.: M. E. Sharpe.

The Economist 2012. Special Report of State Capitalism: The Visible Hand. No. 8768.

The PEW Charitable Trusts 2010. Who's Winning the Clean Energy Race? Growth, Competition and Opportunity in the World's Largest Economies. www.pewtrusts.org/uploaded- 
Files/wwwpewtrustsorg/Reports/Global_warming/G-20\%20Report.pdf?n=5939. Accessed 2March 2014.

Urmee, T., D. Harries and A. Schlapfer 2009. 'Issues related to rural electrification using renewable energy in developing countries of Asia and Pacific.' Renewable Energy 34 (2): 354-357.

Walder, A.G. 1994. 'The Decline of Communist Power-Elements of a Theory of Institutional Change.' Theory and Society 23 (2): 297-323.

Wang, Yu, Sheng Zhou and Hong Huo 2014. 'Cost and CO2 reductions of solar photovoltaic power generation in China: Perspectives for 2020.' Renewable and Sustainable Energy Reviews. 39: 370-380.

Weiss, L. 1998. The Myth of the Powerless State. Ithaca, NY: Cornell University Press.

Wong, J. 2004. 'The Adaptive Developmental State in East Asia.' Journal of East Asian Studies. 4: 345-362.

Yang, M. and R. Pan 2010. 'Harvesting sunlight: Solar photovoltaic industry in China.' Background Brief, No. 562. Singapore: EAI (East Asian Institute)

Zhang Sufang, P. Andrews-Speed, X. Zhao and Y. He 2013. 'Interactions between renewable energy policy and renewable energy industrial policy: A critical analysis of China's policy approach to renewable energies.' Energy Policy. 62: 342-353. 